\title{
SAINT LOUIS AND THE JOCHIDS
}

\author{
Aleksandar Uzelac \\ Institute of History, Belgrade \\ Belgrade, Serbia \\ aleksandar.uzelac@iib.ac.rs
}

Research objectives: To provide an analysis of the relations between the Jochids and the French monarch, Louis IX. Particular attention is dedicated to the channels used by the Tatars to obtain information about the political conditions in Western Europe.

Research materials: Contemporary Western sources including the report of the Franciscan traveler, William of Rubruck, and German chronicles in which Berke's embassy to the French king in 1260 has been recorded.

Results and novelty of the study: The Tatar view of Medieval Europe is an insufficiently researched topic. In the decades that followed the Mongol invasion of Central Europe in 1241-1242, the accounts of Western travelers and chroniclers remain the sole material from which glimpses of the Jochid perspective of the Western world may be discerned. Nonetheless, fragmentary sources at our disposal reveal that the Jochids used Western travelers and envoys to learn more about the Christendom. In this way, the image of Louis IX as the leader of the Christian world was firmly entrenched among the Jochids by the early second half of the thirteenth century. It is attested by Berke's mission sent to Paris in 1260, and also by testimony of William of Rubruck, recorded several years earlier. According to the Flemish Franciscan author, Batu's son Sartak, who regarded Louis IX to be "the chief ruler among the Franks", had heard about the French king from an earlier envoy from Constantinople, Baldwin of Hainaut. The report of Rubruck and other sources at our disposal indicate the importance of the rather neglected Jochid relations with the Latin empire of Constantinople as a channel through which the Tatars gathered valuable reports about the political conditions in the West.

Keywords: Louis IX (Saint Louis), Jochids, Sartak, Berke, William of Rubruck, Constantinople, embassies, diplomats

For citation: Uzelac A. Saint Louis and the Jochids. Zolotoordynskoe obozrenie =Golden Horde Review. 2020, vol. 8, no. 4, pp. 662-674. DOI: 10.22378/2313-6197.20208-4.662-674

It is not an overstatement to say that in the mid-thirteenth century Western Europe was obsessed with the Mongols and their Empire; and for a number of good reasons. The Mongol invasion in 1241-1242 wrought havoc in Poland, Hungary, as well as in Southeast Europe, before the invaders decided to stop their campaign. Their withdrawal puzzled western contemporaries, and the background of their decision to halt the campaign continues to be a matter of scholarly debate up to this day.

The consequent establishment of the Jochid branch of the Chinggisid family in the steppes of Eastern Europe became a potential threat that could not be ignored. The giant neighbor that emerged on the fringes of the Christian ecumene initially provoked fear, but also interest, curiosity, and eventually hope, nurtured in the circles of the Roman Catholic Church that the mysterious "Tartars" would be bap- 
tized and won for Christianity. The same idea attracted other prominent individuals, among them French King Louis IX (1226-1270) or Saint Louis, albeit for a short time. His relations with the Mongol leadership, and the Jochids in particular, will be discussed on the following pages.

Before turning to this topic, it is necessary to note that it is relatively well documented in the source material how the Mongols, including the Jochi's descendants, were perceived through the eyes of their European contemporaries. Unfortunately, the same could not be said for the opposite point of view. To what extent the elite of the Mongol Empire was interested or familiar with the internal conditions of the Western world is still insufficiently researched topic. As P. Jackson rightfully noted, "for those who seek an insight into the Mongol view of the Western world, there are only two avenues - both somewhat indirect, given the absence of any Mongolian narrative source that details the invasion of Europe [...] One way entails gleaning what we can from sources composed by the Mongols' subjects. The other route is through the accounts of the Latin visitors to the Mongol empire" [17, p. 135].

In the decades that immediately followed the Mongol invasion, only the latter path is open for research. Consequently, and unsurprisingly, everything that is known about the dealings of Louis IX with the Chinggisids is recorded in the western sources.

Nevertheless, it is certain that the Mongols showed interest in the western affairs, and that they used various channels at their disposal, including the Christian envoys and missionaries, to gather the relevant information. Several vivid examples attest to that. One such instance is recorded with respect to the travel of Papal envoy, Franciscan John of Plano Carpini. Purportedly, during his stay at Sira Ordu in Mongolia in 1246, Plano Carpini was asked by Great Khan Güyük (12461248) how many rulers there were in the West. He replied that all the others were subordinate to two, the pope and the emperor, and after being then asked which of these was the greater, he replied, "the pope" [36, I, p. 297] ${ }^{1}$. Moreover, a companion of Plano Carpini, monk C. de Bridia, recorded that the "even the Tartars recognize the apostolic authority of the Pope throughout the West" [16, p. $4 ; 47$, p. 54]. It seems that the similar impression was already present in the church circles even before Plano Carpini's mission took place. In the report of Russian archbishop Peter, submitted at the Council of Lyons in 1245, it was stated that the Mongols understood that "the pope was the master of the world, and would very much like to visit him" [35, p. 155].

Diplomatic efforts of Batu, leader of the Mongol invasion of Europe, indicate that he had at least a vague idea about the western affairs. In 1237, almost four years before his army crossed the Carpathians, Batu repeatedly sent letters that contained the ultimatum of submission to Hungarian king Béla IV (1235-1270). Their contents are recorded by a Dominican traveler and missionary, friar Julian, who brought one of these letters to the Hungarian king from Eastern Europe [13, p. 380, 396, n. 43; 39, p. 42-43]. Such ultimatums were the well-established Mongol practice in their communication with the foreign courts, and almost all of their correspondence with European powers in the next two decades, with one notable exception, which will be

\footnotetext{
${ }^{1}$ Nonetheless, John of Plano Carpini feared the possibility that Tatar envoys might accompany him on his return voyage, test the veracity of his words, and see the dissensions and wars among his fellow Christians [cf. 15, p. 327-328; 44, p. 125-126].
} 
further noted, carried such tones [49, p. 378-413]. Moreover, in 1238, according to chronicler Alberic of Trois-Fontaines, the "Tartar king" (obviously Batu) allegedly sent a letter to Emperor Frederick II Hohenstaufen (r. 1212-1250), requesting his submission and offering him place in his court. Unlike the Hungarian ruler, who refused to give any kind of answer in return, the emperor sent a witty response, humbly stating that "he knows something about the birds and that he would make a good falconer" [4, p. $943 ; 13$, p. 399; 30, p. 475; 39, p. 43].

At the time of the Mongol invasion, unlike Béla IV and Frederick II, Louis IX of France had no direct contacts with the invaders. Aware of the threat and initially stricken with fear, he put a lot of effort to learn about their strength and plans. According to a well-known anecdote recorded by English chronicler Matthew Paris, in the conversation with his mother Blanche of Castile, the king remarked that "either we shall push them back to their home Tartarus, whence they came, or they will carry all of us to heaven" $[25, \mathrm{IV}, \mathrm{p}$. 111]. The play of words that connected the name of the invaders with proverbial hell from Greek mythology was not the invention of Louis IX. At the time of the Mongol invasion it widely circulated in Europe, but it was a bitter irony that several years later the French king drastically changed the attitude towards the "newcomers from Tartarus" and made a lot of effort to secure the alliance with them.

$$
* * *
$$

The first direct contacts between Louis IX and the Mongols predated the king's expedition to Egypt in what used to be known as the Seventh Crusade. In the fall of 1248, during his stay in Cyprus and final preparations for the campaign, Louis IX was visited by two Nestorian Christians, Mark and David, messengers of Mongol commander Eljigidei, stationed in northern Persia. At the meeting with the king in Nicosia, they proposed alliance on behalf of their master and the great khan Güyük. The messengers offered the Mongol aid for the capture of Jerusalem and revealed that both Eljigidei and Güyük had been baptized [2, p. 145-151; 20, p. $74-75 ; 25$, VI, p. $163-165 ; 27$, p. $168-169 ; 38$, p. $68-69 ; 40$, p. 128-132; 46, p. 1316-1317].

The offer of the two Eljigidei's messengers, although greatly differed in its nature from the earlier Mongol requests for submission, was not without its precedent. At the council of Lyons in 1245, a decision was made to send several missions, whose members were mendicant friars, to "the Tartars". Plano Carpini went to the Pontic Steppes and from there to Mongolia, Dominican Ascelin of Cremona was directed to the camp of Eljigidei's predecessor Baiju in Armenia, while the third embassy, led by his colleague, Andrew of Longjumeau, went further east, and eventually reached Tabriz. It was there that Longjumeau met Simeon Rabban Ata, prominent Nestorian cleric who composed three letters, for Pope Innocent IV (1243-1254), Frederick II, and Louis IX respectively. In the last document he plead the French king to be well disposed towards Nestorian community in the Holy Land ${ }^{2}$. The letter of Eljigidei bore similarities with the one sent by Simeon

\footnotetext{
${ }^{2}$ Matthew Paris recorded a rumor that already in 1247 Louis IX received an order from the "king of the Tartars" to become his subject [25, IV, p. 607-608]. This embassy is not mentioned in any other source, and possibly the rumor was a distorted reflection of the initial contacts between the Nestorian community in the Mongol domains and the French king.
} 
Rabban Ata, and it is logical to assume that the baptism of the great khan was a deception, conceived by the members of the Nestorian community, rather than by the Mongol commander himself [3, p. 178-179; 9, p. 291-292].

Thus, even before the meeting with Eljigidei's envoys, Louis IX had the opportunity to hear rumors in Cyprus about the benevolence of Mongol elite towards the Christians. The words of David and Mark further encouraged the king, and he decided to send Andrew of Longjumeau, who was in his entourage, with his brother William and John of Carcassone, and with a small chapel as a gift, to the khan. At that time Güyük was already dead, but the news about his demise did not reach Levant. Quite the contrary, during the next year, rumors about the religious conversion of the "chief of the Tartars" that were inspired by the events in Cyprus, circulated in Western Europe [25, V, p. 80].

Much to his dismay, Longjumeau realized that they have no basis in reality. After the meeting with Güyük's widow, Oghul Qaimish, who acted as an interim regent of the Empire and instead of the alliance he hoped for, the king's emissary received another request for submission and recognition of the Mongol overlordship [2, p. $151-152 ; 29$, p. 50-54, 66-76; 40, p. 133-136; 46, p. 1317-1318]. When the news of the failure reached Palestine after Longjumeu's return in 1251, Louis IX bitterly regretted for believing the Mongol intentions in the first place. According to his biographer Jean de Joinville, "the king repented sorely that he had ever sent the mission to the Tartars" [20, p. 268-271; 27, p. 258-259; cf. 38, p. 109].

This diplomatic exchange and its disastrous outcome are well-known, as well as its indirect consequences. After the election of the new great khan Möngke (1251-1259), Eljigidei, the initial creator of the idea of the Frankish-Mongol cooperation in Levant, was put to death as an enemy of the new regime in Karakorum [1, p. 152], and in early 1254, Louis IX finally returned from Palestine to France. The king's eastern adventure and ambitiously promoted crusade turned to be fiasco. Moreover, it seemed that for a time the French king was forgotten in the Mongol world, but it was not destined to be.

Less than a decade later, Louis IX received two embassies from the Chinggisid Empire. The first of them is recorded in the Annals of the anonymous Minorite from Erfurt, composed in ca. 1265, and repeated in mid-fourteenth century Chronicle of Johannes of Winterthur and Chronicle of Reinhardsbrunn. According to these sources, in which the same text is repeated with slight discrepancies: "in the year of our Lord 1262, the Tartar king sent honorific emissaries, some twenty-four noble Tartars with two friars of the Dominican order who were the translators of the languages, to the French king Louis, in order that he submit, with his kingdom, to the power of the Tartars. Otherwise, they would have attacked France in the near time. King Louis took the council with the dignitaries of his kingdom, and fiercely rejected that. He held the emissaries with honor in Paris and sent them in peace to Pope Alexander" [7, p. 202; cf. 6, p. 15; 8, p. 623] $]^{3}$.

\footnotetext{
3 “Anno Domini 1262. rex Tartarorum misit sollempnes nuncios, circiter 24 nobiles Tartaros cum duobus fratribus ordinis Predicatorum, qui essent interpretes linguarum, ad regem Francie Ludewicum, ut se et totum regnum Francie dicione subiceret Tartarorum; alioquin Franciam impugnaret tempore procedente. Quod Ludewicus rex, habito consilio cum primoribus regni sui, constanter rennuit; ipsos tamen nuncios honorifice Parisius tenuit et usque ad papam Alexandrum pacifice remisit".
} 
The embassy of the unnamed "Tartar king" to Louis IX has often been equated with the second mission, sent in 1262 by Hülëgu (1258-1265), Mongol ruler in Persia and founder of the Ilkhanate. In the face of his conflict with the Jochids, and the emerging Jochid-Mamluk alliance, Hülëgu renewed abandoned Eligidei's plans. He urged the French king to take another expedition to the Holy Land and to block the Levantine coast with his fleet. In the letter, Hülëgu not only praised the king's virtues and leadership, but even referred to the chapel he previously sent to Güyük. The letter was probably carried by Hülëgu's confidant, certain John the Hungarian (Johannes Ungarus), but it never reached its destination. The embassy was captured by king Manfred of Sicily (1258-1266), the Pope's adversary and illegitimate son of Frederick II, although John eventually managed to rescue himself from the captivity, visit pope Urban IV $(1261-1264)$ and to inform him of the purpose of his voyage $[17$, p. $166 ; 21$, p. 117-137; 23, p. 230; 28, p. 245-260; 37, p. $90-92]^{4}$.

Despite the frequently repeated opinion of some scholars, who equated the two above-described missions as a single diplomatic effort [33, p. 295-303; 37, p. 328], there is no doubt that the embassy recorded by the German chroniclers, had no relation to the Hülëgu's proposal. The aims and tones of the two diplomatic exchanges were quite different, and they did not take place simultaneously. Namely, the year of 1262, recorded in the Annals of Erfurt, Chronicle of Johannes of Winterthur, and Chronicle of Reinhardsbrunn, is incorrect. Pope Alexander IV (1254-1261) died on May 25, 1261, after he convoked the council in Viterbo in order to deal with the Tatar threat [12, p. 293; 15, p. 402; 36, II, p. 152; 40, p. 193]. Therefore, the embassy must have reached Paris a year earlier, in 1260. It was two years before the mission of John the Hungarian, on Hülëgu's behalf, took place.

In fact, as some researchers rightfully pointed out, the Tatar ruler who stood behind the earlier embassy, recorded in the German chronicles, could have been none other than the Jochid leader Berke (1257-1266), Batu's younger brother and successor [12, p. 293; 17, p. 123-124]. The embassy coincided with the eruption of conflict between Kublai and Arik-Böke over the inheritance of the imperial throne after the death of their brother Möngke, and more importantly, with the apogee of Berke's reinvigorated attempts to pursue offensive to the West. Therefore, in order to understand the background of Berke's ultimatum sent to Louis IX, it is convenient to briefly look at the contemporary events in Central and Eastern Europe.

The ominous announcement of the new Jochid expansion happened soon after Berke's enthronement in 1257. A year later, Tatar leader Burundai received submission from the princes of Halych and Volhynia and raided Lithuanian lands. In the fall of 1259, Burundai again mobilized Tatar forces and their Rus' allies in the campaign against Little Poland. The lands around Kraków and Sandomierz were thoroughly devastated before the Tatars retreated in the spring of 1260 [5, p. $1-16 ; 12$, p. $288-290 ; 22$, p. 171-201; 42, p. 239-251]. The campaign was a powerful demonstration of force, and in the meantime, Berke used the similar means of diplomatic pressure against the Hungarian king, as Batu did two decades

\footnotetext{
${ }^{4}$ The text of Hülëgu's letter, written in Latin on April 10, 1262 in Maragha, was preserved in a manuscript from Salzburg, where it was copied by a certain scribe Nicholas ("Nycolaus") in 1344 [28, p. 245].
} 
earlier. In 1259, he requested from Béla IV to send him a quarter of his military resources as a support in the future Tatar wars. Moreover, he proposed a marital conjunction either between his daughter and Bela's son, or between his son and a daughter of the Hungarian king. Despite the threatening words that the refusal would provoke another Tatar invasion of Hungary, the prospects of such, forcingly imposed alliance, were unlikely. Béla IV informed Alexander IV about the Tatar ultimatum, but received no words of encouragement in return; only a warning from the pope that any deal with the Tatars would be harmful to his reputation as a Christian king [12, p. 296-297; 39, p. 58-59; 41, p. 239-241].

The mission to Paris in 1260 was thus obviously a part of Berke's elaborated political maneuvering, aimed to show that the Tatars were ready for the new massscale invasion of Europe. Pope Alexander IV was convinced that the threat was real and imminent. He insisted that "the Tartars may yet attempt a hostile entrance into Europe with a mighty orgy of massacre upon the inhabitants of those regions (Hungary and Poland). For they plan to annihilate the mighty heads of Christendom, and after overthrowing the thrones of kings and seats of powerful rulers, secure the sole rulership of the entire globe" [10, p. 338; 12, p. 293]. For the pope, it probably came as an unexpected and bitter blow, considering the earlier well-disposed intentions of the Jochid leader towards Christian missionaries in his lands, which he expressed to papal emissaries [14, p. 112-113; 23, p. 213-215].

Be that as it may, Berke's plans were soon put on hold indefinitely. In the course of 1261 and 1262, enmity between him and Hülëgu turned into the full-scale war in Transcaucasia. It signaled the beginning of an end of the unified Mongol empire, although it seems that the magnitude of the split within the Tatar world was not fully recognized in the West until the late sixties of the thirteenth century.

In such circumstances, the Jochid embassy to Paris left no practical consequences. However, the episode remains important for several other reasons. It indicates that, in the eyes of the Jochids, the position of Louis IX in the Christian world was conspicuously similar to Emperor Frederick II Hohenstaufen on the eve of the Mongol invasion. Namely, in both instances, Batu and Berke deliberately targeted the Hungarian king as their immediate neighbor, and the monarch that was, from their perspective, considered to be the head of Christendom. From the political point of view, patterns and tones of the ultimatums of Jochi's descendants remained almost the same.

Although it was the unique attempt of the Jochids to force Louis IX into submission, and the only recorded instance of their mutual contacts, the Tatars in the Pontic steppes learned about the king of France and his prestige a long time before the Berke's embassy took place. This fact is revealed by the report of Franciscan traveler William of Rubruck to the court of great khan Möngke, and therefore it is necessary to turn our attention to this extremely valuable source that sheds muchneeded light on early contacts between the Jochids and Christian world.

$$
* * *
$$

In late 1252 , or more probably in early 1253 , William of Rubruck left the French crusading army in Palestine and sailed to Constantinople, the capital of the Latin Empire, established after the Fourth Crusade in 1204. The journey was motivated by the rumors that Batu's son Sartak was a Christian. After the failed mission of Longjumeau. Louis IX insisted that Rubruck should not allow himself 
to be taken for another French ambassador, but he agreed to compose a letter for the Mongol prince [17, p. 99; 18, p. 43-45; cf. 32, p. 55-60]. In such informal capacity, the Flemish Franciscan met in Constantinople with the Latin emperor Baldwin II (r. 1227-1261), and afterwards, on May 7, 1253, departed from Bosporus in the company of his colleague, Friar Bartholomew of Cremona, an interpreter, a clerk, and a servant. Rubruck and his retinue passed through the Crimean port of Soldaia (Sudak) and after relatively uneventful journey they reached the camp of Sartak, situated between the rivers Don and Volga. It was there that Rubruck met one of the companions of David, Eljigidei's diplomat "who had been to Cyprus (during the negotiations with Louis IX in 1248) and had passed on everything he had seen" [18, p. 116; 44, p. 201].

Considering the role of the Nestorian dignitaries in the previous contacts of the French king with the Mongol leadership in Persia, and their presence in the Sartak's camp, it would be logical to assume that the reputation of Louis IX among the Jochids owed much to their efforts. Nonetheless, Rubruck explicitly spoke about another man, who informed Batu's son about the French king. As he related in his report, dedicated to Louis IX: "Sartak further enquired who was the chief ruler among the Franks. 'The Emperor', I said, 'if he held his territory unchallenged'. 'No', he said, 'it is the King'. For he had heard of you from the lord Baldwin of Hainault" [18, p. 115; 44, p. 201].

This intriguing passage deserves due consideration. First, with respect to the spurious mention of the "emperor", and second, to the man recorded as Sartak's source of information. At the time of Rubruck's voyage to the East, Frederick II Hohenstaufen was not among the living. He died on December 13, 1250, and his possessions in Germany and Southern Italy, as well as the titular crown of Jerusalem, passed to his son, Conrad IV (1250-1254). However, due to his bitter struggle with the pope, Conrad IV was not able to assume the imperial crown, and technically, the throne remained vacant. Whether this fact was known to Sartak could be only guessed, but it may be argued that the Jochid prince, who insisted that the Louis IX was the "chief ruler among the Franks", was more concerned with the practical disposition of power than with the formal Christian ruling hierarchy in which the emperor stood above kings, while Rubruck had obviously the latter in mind.

Baldwin of Hainaut, who appears as Sartak's informant is a well-known historical person. He played an important, albeit sometimes neglected role in the contacts between the Christian world and the Tatars [31, p. 115-121; 43, p. 63-65; 45, p. 122-129]. Possibly a cousin of the namesake Latin Emperor Baldwin II, he rose to prominence in 1239, when he married a Cuman princess, as part of the agreement of the short-term alliance established between the Franks in Constantinople and Cuman fugitives from the Pontic steppes [4, p. 950]. Thanks to his Cuman wife, Baldwin of Hainaut was probably able to learn her language and to get acquainted with the customs of the Pontic Steppes. Therefore, it is not surprising that in 1250 or 1251 , he was chosen for a delicate and far-reaching political mission.

The Frankish elite in Constantinople, pressed by the growing power of their neighbor, the Empire of Nicaea and its plans for the restoration of Byzantium, decided to seek an alliance with the Tatars and fulfillment of this task was put in 
hands of Baldwin of Hainaut. On the basis of Rubruck's report it is known that Baldwin met with Sartak and afterwards traveled as far as Mongolia, but nothing else [18, p. 115, 200; 44, p. 201, 268]. However, the outcome of Baldwin's mission can be guessed from another passage in the Rubruck's report. Namely, it led to the establishment of the diplomatic relations between the Latin empire and the Jochids, which is confirmed by the fact that Rubruck carried the letters of recommendation, given to him by emperor Baldwin II, when he set out from Constantinople. They proved to be of value in order to secure him and his companions the free passage through the Jochid domains 5 .

The reminiscence of the talks between the Jochid prince and the diplomat from Constantinople, recorded by Rubruck, is another vivid example that illustrates how the Tatars endeavored to learn as much about the conditions in the West as possible from westerners themselves. The talks between Baldwin of Hainaut and Sartak resemble Güyük's enquiry to Plano Carpini, or Kublai's thorough questioning of Venetian traders Niccolò and Maffeo Polo concerning the pope and secular rulers in the West, after they were granted an audience at his court [24, p. 77-78].

Eager to get insight into the Christian world, the Chinggisids particularly valued adventurers, willing to enter their service as interpreters and agents. Such was a certain English Knight Templar from Acre, who acted as Batu's emissary and interpreter, before he was eventually captured by the forces of duke of Austria in 1241, and whose personal experiences intrigued chronicler Matthew Paris in distant England [25, IV, p. 274]. Hülëgu's emissary John the Hungarian is another such example, and to the list we may add certain Richard, Hülëgu's scribe who probably composed his letter sent to Louis IX in 1262 [2, p. 153; 23, p. 230; 28, p. 251; 34, p. 301]. The two Dominicans, who acted as interpreters of Berke's embassy to Paris, but whose names did not come to us, were hardly "the Tatar collaborators", but they were employed in the similar role. Among the westerners whose destiny was connected with the Chinggisids, Baldwin of Hainaut stands as a somewhat unique example. He was not a man in the Tatar service, but it would be wrong to consider him an ordinary envoy. He obviously had a considerable influence on Sartak, and the faith put in his words by the Jochid prince is a fact that should not be ignored.

Diplomatic relations between Latin Empire of Constantinople and the Jochids, were discussed in detail elsewhere [43, p. 62-75]. Here is enough to note that the precarious position of the Latin Empire illustrates why the idea of ChinggisidFrankish collaboration, initially agitated by the Nestorian church of the East, also gained prominence in Constantinople, and why the French king, who was at that time in the Holy Land and to whose support the Franks in Constantinople put a lot of hope, became an object of the talks between Sartak and Baldwin of Hainaut. Besides, it is almost certain that the rumors about Sartak's adherence to Christianity, albeit in its Nestorian form, that reached Louis IX in Palestine, came from Constantinople after Baldwin's return. Philippe de Toucy, for a time regent of the Latin empire and informant of the king's biographer Jean de Joinville, stayed

\footnotetext{
${ }^{5}$ The Mongol commander in the hinterlands to the north of Crimea had trouble to decipher the contents of the recommendations, because they were written in Greek language, which nobody in his camp was able to read. He promptly sent for the translator in Soldaia, and as soon as the contents of the letter were presented to him, Rubruck and his companions were provided with guides who escorted them to Sartak [18, p. 98; 44, p. 188].
} 
with the French king in Palestine during 1251-1252, and he is the most likely candidate who informed him about the religious inclinations of the Jochid prince.

Moreover, it is possible that the establishment of the relations between the Jochids and the Latin empire, motivated Sartak to look more closely into the western affairs. A year after Rubruck's departure from Constantinople, an Armenian adventurer, a cleric named John, appeared in Italy professing to be Sartak's personal confessor and envoy. Pope Innocent IV received him with due honors and on August 29, 1254 sent a long letter to his master in which he congratulated him on being baptized and encouraged him to publicly declare his allegiance to the Christian faith and to convert his subjects [26, p. 204-206; 29, p. 78-79; 48, p. 592m-n]. John the Armenian passed through southern Italy, where he was captured for a short time by papal adversary Conrad IV, before he managed to arrive in Rome (his misfortunes strikingly resembled those experienced by John the Hungarian almost a decade later), and it is possible that he traveled via Constantinople. It is, naturally, just a possibility, and the papal letter to Sartak was probably passed through different route. The bearers of the letter were five Dominicans whom Rubruck met in Ani, Armenia, in February 1255, on his return voyage from Mongolia [12, p. 286-287; 18, p. 270-271; 44, p. 325-326]. Whether the letter from Rome ultimately reached the Pontic Steppes and was delivered to Sartak as planned, is not known.

The relations between the Latin empire and the Jochids remained cordial even at the time when Berke reinvigorated his plans of the western expansion, sent the embassy to Paris to request submission from Louis IX, and when Pope Alexander IV attempted to raise awareness of the incoming Tatar attack on Christendom. It is illustrated by the voyage of Niccolò and Maffeo Polo, who set out from Constantinople in 1260 . They were graciously received by Berke, and earned much profit from their trading activities in Sarai, Bulgar, and Ukek in the Middle and Lower Volga region [24, p. 74-75]. The contacts between the Franks in Constantinople and the Jochids were broken only in 1261, when Nicean forces were able to recapture the city of Bosporus, and to liquidate the Latin empire.

The attempts to secure the Tatar support did not save the Latin Empire from its inevitable destiny. Nonetheless, during the previous decade, the relations established between Constantinople and Sarai opened the door for the traders and diplomats from the West to get familiar with the Chinggisid world. In return, the Jochids got the possibility to learn more about the Christian Europe, which even prominent Persian polyhistor and Mongol official, Rashid al-Din, decades later characterized as the world of many nations and countries waging war with each other $[19$, p. 54]. The image of Louis IX as the leader of the western world, in which Sartak was convinced at the time of Rubruck's voyage, and which Berke tried to exploit several years later, at the time when he contemplated the new campaign towards the West, remains an intriguing echo of the close contacts between the Franks from Constantinople and the Jochids. 


\section{REFERENCES}

1. Abramowski W. Die chinesischen Annalen von Ögödei und Güyük, Übersetzung des 2. Kapitels des Yüan Shih. Zentralasiatische Studien. 1976, vol. 10, pp. 117-167. (In German)

2. Aigle D. The letters of Eljigidei, Hülegü, and Abaqa: Mongol overtures or Christian ventriloquism?. Inner Asia. 2005, vol. 7/2, pp. 143-162.

3. Aigle D. The Mongol Empire between Myth and Reality. Leiden; Boston: Brill, 2014. 394 p.

4. Albrici monachi Triumfontium Chronicon. Scheffer-Boichorst P. (ed.). Monumenta Germaniae historica, Scriptores, XXIII. Hannoverae: Impensis Bibliopolii A. Hahniani, 1874, pp. 631-950. (In Latin)

5. Baronas D. The encounter between forest Lithuanians and steppe Tatars in the time of Mindaugas. Lithuanian Historical Studies. 2006, vol. 11, pp. 1-16

6. Chronica Iohannis Vitodurani. Monumenta Germaniae historica, Scriptores rerum Germanicarum, nova series, III. Baethgen F. (ed.). Berolini: Apud Weidmannos, 1924. xxxvii + 332 p. (In Latin and German)

7. Chronica minor auctore Minorita Erphordiensi. Holder-Egger O. (ed.). Мопиmenta Germaniae historica, Scriptores, XXIV. Hannoverae: Impensis bibliopolii Hahniani, 1879, pp. 172-204. (In Latin)

8. Chronica Reinhardsbrunnensis. Holder-Egger O. (ed.). Monumenta Germaniae historica, Scriptores, XXX/1. Hannoverae: Impensis bibliopolii Hahniani, 1896, pp. 490 656. (In Latin)

9. Claverie P.V. Deux lettres inedites de la première mission en Orient d'André de Longjumeau. Bibliothèque de l'École des chartes. 2000, vol. 158/1, pp. 283-292. (In French)

10. Crusade and Christendom: Annotated Documents in Translation from Innocent III to the Fall of Acre, 1187-1291. Bird J., Peters E., and Powell J.M. (eds). Philadelphia: University of Pennsylvania Press, 2013. xxii +514 p.

11. Giovanni di Pian di Carpine. Storia dei Mongoli. Menestò E. et al. (eds). Spoleto: Centro Italiano di studi sull'alto medioevo, 1989. 522 p. (In Latin and Italian)

12. Hautala R. Ot Batu do Dzhanibeka: voennye konflikty Ulusa Dzhuchi s Pol'shey i Vengriey (1) [From Batu to Janibek: Military Conflicts of the Ulus of Jochi with Poland and Hungary (1)]. Zolotoordynskoe obozrenie=Golden Horde Review. 2016, vol. 4/2, pp. 272-313. (In Russian)

13. Hautala R. Ot "Davida, tsarya Indiy" do "nenavistnogo plebsa satany": antologiya rannih latinskih svedeniy o tataro-mongolah [From "David, Emperor of Indies" to the "Hateful Plebs of Satan": Anthology of Early Latin Information about the TatarMongols]. Kazan: Marjani Institute of History of Tatarstan Academy of Sciences, 2015. 496 p. (In Russian and Latin)

14. Hautala R. V zemlyah "Severnoy Tartarii". Svedeniya latinskih istochnikov o Zolotoy Orde v pravlenie hana Uzbeka (1313-1341) [In the Lands of "Northern Tartary". Information of the Latin Sources about the Golden Horde during the Reign of Özbeg Khan (1313-1341)]. Kazan: Marjani Institute of History of Tatarstan Academy of Sciences, 2019. 976 p. (In Russian and Latin)

15. Hermanni Altahensis annales. Jaffé P. (ed.). Monumenta Germaniae historica, Scriptores, XVII. Hannoverae: Impensis bibliopolii Hahniani, 1861, pp. 381-407. (In Latin)

16. Hystoria Tartarorum C. de Bridia monachi. Önnerfors A. (ed.). Berlin: De Gruyter, 1967. x + 44 p. (In Latin)

17. Jackson P. The Mongols and the West (1221-1410). Harlow: Routledge, 2005. $448 \mathrm{p}$. 
18. Jackson P. and Morgan D. (eds \& trans.). The Mission of Friar William of Rubruck: His Journey to the Court of the Great Khan Möngke 1253-1255. London: Hakluyt Society, 1990. 312 p.

19. Jahn K. (ed.). Die Frankengeschichte des Rašid ad-Din. Wien: Verlag der Österreichischen Akademie der Wissenschaften 1977. 109 p. (In German)

20. Jean de Joinville. Histoire de Saint Louis. De Wailly N. (ed.). Paris: Typ. de Firmin Didot frères, 1874. 689 p. (In French)

21. Ligeti L. Joannes Ungarus és az 1262. évi mongol követjárás [Joannes Ungarus and the Mongol Embassy of 1262]. Az MTA Nyelv-és Irodalomtudományi Osztályának Közleményei [Announcements of the Department of Linguistics and Literature of the Hungarian Academy of Sciences]. 1981, no. 32, pp. 117-137 (In Hungarian)

22. Krakowski S. Polska $w$ walce $z$ najazdami tatarskimi $w$ XIII wieku [Poland in the Fight against Tartar Invasions in the thirteenth century]. Warszawa: Wydawn. Ministerstwa Obrony Narodowej, 1956. (In Polish)

23. Lupprian K.-E. Die beziehungen der Päpste zu den islamischen und mongolischen Herrschern im 13. Jahrhundert. Città del Vaticano: Biblioteca Apostolica Vaticana, 1981. 328 p. (In German)

24. Marco Polo. The Description of the World, vol. II. Moule A.C. and Pelliot P. (eds and trans.). London: G. Routledge, 1935. 595 p.

25. Matthaei Parisiensis Chronica Majora, I-VII. Luard H.R. (ed.). London: Longman \& co, 1872-1882. (In Latin)

26. Mayorov A.V. Mongoly, Nikeya i Rim v seredine XIII stoletiya [The Mongols, Nicaea, and Rome in the middle of the thirteenth century]. Zolotoordynskaya tsivilizatsiya=Golden Horde Civilization. 2012, vol. 5, pp. 193-208. (In Russian)

27. Marzials F. (trans.). Memoirs of the Crusades by Villehardouin and de Joinville. London; Toronto: J.M. Dent \& Sons, 1921. 340 p.

28. Meyvaert P. An unknown letter of Hulagu, Il-Khan of Persia, to King Louis IX of France. Viator. 1980, vol. 11, pp. 245-260.

29. Pelliot P. Les Mongols et la Papauté. Revue de l'Orient chrétien. 1931-1932, vol. 8 (28), pp. 3-84. (In French)

30. Reichert F. Geographie und Weltbild am Hofe Friedrichs II. Deutsches Archiv für Erforschung des Mittelalters. 1995, vol. 51, pp. 433-491. (In German)

31. Richard J. À propos de la mission de Baudouin de Hainaut: l'empire latin de Constantinople et les Mongols. Journal des Savants. 1992, vol. 1, pp. 115-121. (In French)

32. Richard J. Sur le pas de Plancarpin et de Rubrouck: La lettre de Saint Louis a Sartaq. Journal des Savants. 1977, vol. 1, pp. 49-61. (In French)

33. Richard J. Une ambassade mongole à Paris. Journal des Savants. 1979, vol. 4, pp. 295-303. (In French)

34. Roberg B. Die Tartaren auf dem 2. Konzil von Lyon 1274. Annuarium Historiae Conciliorum. 1973, vol. 5, pp. 241-302. (In German)

35. Ruotsala A. Europeans and Mongols in the middle of the thirteenth century: Encountering the Other. Helsinki: Finnish Academy of Science and Letters, 2001. 169 p.

36. Salimbene de Adam. Chronica. Bernini F. (ed.), vol. I-II. Bari: Giusepe Laterza \& figli, 1942. (In Latin)

37. Schmieder F. Europa und die Fremden. Die Mongolen im Urteil des Abendlandes vom 13. bis in das 15. Jahrhundert. Sigmaringen: Thorbecke Verlag, 1994. 396 p. (In German)

38. Shirley J. (ed.). Crusader Syria in the thirteenth century. The Rothelin Continuation of the History of William of Tyre with Part of the Eracles or Acre Text. London; New York: Routledge, 2016. vi + 156 p.

39. Sinor D. Les relations entre les Mongols et l'Europe jusqu'à la mort d'Arghoun et de Bela IV. Cahiers d'histoire mondiale. 1956, vol. 3, pp. 39-62. (In French) 
40. Soranzo G. Il Papato, l'Europa cristiana e i Tartari. Milano: Pubblicazioni Dell’Università Cattolica del Sacro Cuore, 1930. xii + 624 p (In Italian)

41. Theiner A (ed.). Vetera monumenta historica Hungariam sacram illustrantia, vol. I. Osnabrück: Otto Zeller, 1968. 837 p. (In Latin)

42. Urbanski R. Tartarorum gens brutalis - Trzynastowieczne najazdy mongolskie $w$ literaturze polskiego średniowiecza na porównawczym tle piśmiennictwa łacińskiego antyku i wieków średnich. Warszawa: Instytut Badań Literackich, 2009. 323 p. (In Polish)

43. Uzelac A. Latin Empire of Constantinople, the Jochids and Crimea in the midthirteenth century. Zolotoordynskoe obozrenie=Golden Horde Review. 2015, vol. 2/3, pp. 62-75.

44. van den Wyngaert A. (ed). Sinica Franciscana, Vol. I: Itinera et relationes fratrum minorum saeculi XIII et XIV. Quaracchi, Firenze: Collegio S. Bonaventura, 1929. 637 p. (In Latin)

45. Verlinden C. Boudewijn van Henegouwen: een onbekende reiziger door Azië. Tijdschrift voor Geschiedenis. 1952, vol. 65, pp. 122-129. (In Dutch)

46. Vincentius Bellovacensis. Speculum Quadruplex sive Speculum Maius: Naturale, Doctrinale, Morale, Historiale, Vol. 4: Speculum historiale. Graz: Akademische Druck u. Verlagsanstant, 1965. 1334 p. (In Latin)

47. The Vinland Map and the Tartar Relation. Skelton R.A., Marston Th.E., and Painter G.D. (eds and trans.). New Haven: Yale University Press, 1965. xii + 291 p.

48. Vita Innocentii papae IV scripta á fratre Nicolao de Curbio ordinis minorum. Rerum Italicarum scriptores, III. Muratori L.A. (ed.). Mediolani, 1723, pp. 592a-592o. (In Latin)

49. Voegelin E. The Mongol orders of submission to European powers, 1245-1255. Byzantion. 1940/41, vol. 15, pp. 378-413.

About the author: Aleksandar Uzelac - Ph.D. (History), Senior Research Fellow, Institute of History, Belgrade (36/II, Kneza Mihaila Str., Belgrade 11000, Serbia); ORCID: 0000-0003-0626-2928. E-mail: aleksandar.uzelac@iib.ac.rs

Received June 17, 2020 Accepted for publication November 25, 2020

Published December 29, 2020

\title{
Святой людовик и ДжУчиды
}

\author{
Александар Узелац \\ Институт истории, Белград \\ Белград, Сербия \\ aleksandar.uzelac@iib.ac.rs
}

Цель исследования: анализ отношений между Джучидами и французским королем Людовиком IX. Особое внимание уделяется каналам, использовавшимся татарами в Понтийских степях для получения информации о политической ситуации в Западной Европе.

Материалы исследования: синхронные западные источники. Особенно важными для темы исследования являются «Итинерарий» фламандского францисканца Гильома де Рубрук и хроники, в которых засвидетельствовано посольство Берке к французскому королю в 1260 г. 
Результаты и новизна исследования: татарский взгляд на средневековую Европу - недостаточно исследованная тема. В течение десятилетий, последовавших за монгольским нашествием, рассказы западных путешественников и хронистов остаются единственным материалом, на основе которого можно судить о взглядах Джучидов на Западную Европу. Тем не менее фрагментарные источники в нашем распоряжении показывают, что Джучиды использовали западных путешественников и посланников с целью получения информации о христианском мире. Следовательно, образ Людовика IX как предводителя христиан укоренился в джучидской среде в начале второй половины XIII в. Об этом свидетельствуют посольство Берке, отправленное в Париж в 1260 г., а также слова Гильома де Рубрук, записанные несколькими годами ранее. Согласно Гильому де Рубрук, сын Бату, Сартак, который считал Людовика IX «главным правителем франков», узнал о короле от его предшественника и путешественника, Бодуэна де Эно из Константинополя. Гильом де Рубрук и другие источники указывают на важность отношений Джучидов с Латинской империей, как канал, который татары использовали для того, чтобы познакомиться с западным миром.

Ключевые слова: Людовик IX (Святой Людовик), Джучиды, Сартак, Берке, Гильом де Рубрук, Константинополь, посольства, дипломаты

Для цитирования: Uzelac A. Saint Louis and the Jochids // Золотоордынское обозрение. 2020. Т. 8, № 4. С. 662-674. DOI: 10.22378/2313-6197.2020-8-4.662-674

Сведения об авторе: Александар Узелац - $\mathrm{PhD}$ (история), старший научный сотрудник Института истории (Белград) (11000, ул. Кнеза Михаила, 36/II, Белград, Сербия); ORCID: 0000-0003-0626-2928. E-mail: aleksandar.uzelac@iib.ac.rs

Поступила 17.06.2020 Принята к публикаиии 25.11.2020

Опубликована 29.12.2020 